\title{
ROLE OF LOCAL GOVERNANCE DURING THE COVID-19 PANDEMIC: EVIDENCE FROM KERALA EXPERIENCE
}

\author{
Vimal V 1 (iD, Dr. Vipin Chandran K P 2 (iD \\ 1 Doctoral Scholar in Economics, Kannur University, Kerala, India \\ ${ }^{2}$ Assistant Professor and Research Guide, Department of Economics, Krishna Menon Memorial \\ Government Women's College Kannur, Pallikunnu (P.0), 670504 (Pin), Kerala, India
}

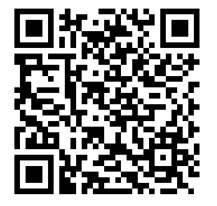

DOI: https://doi.org/10.29121/granthaalayah.v8.i8.2020.1198

Article Type: Research Article

Article Citation: Vimal V, and Dr. Vipin Chandran K P. (2020). ROLE OF LOCAL GOVERNANCE DURING THE COVID-19 PANDEMIC: EVIDENCE FROM KERALA EXPERIENCE. International Journal of Research -GRANTHAALAYAH, 8(8), 319-327.

https://doi.org/10.29121/granthaa layah.v8.i8.2020.1198

Received Date: 16 August 2020

Accepted Date: 31 August 2020

Keywords:

Local Self Governance

Kerala

COVID-19 Pandemic

\section{ABSTRACT}

In local governance around the world are in crisis with COVID -19 on local health care and economy. The process widens the social-economic issues and inequalities. The local self-governments are in the front line to serve the people, they have taken several initiatives to prevent the spread and helping patients who were tested as positive. In Kerala as per the census 2011, there are "1200 Local Self Governments (LSG) in Kerala which include 941 Grama Panchayaths, 152 Block Panchayaths, 14 District Panchayath, 87 Municipalities, and 6 Municipal Corporations." The lack of resource availability with increased needs creating a burden of efficient distribution through proper planning but the COVID -19 process destroyed the whole process. At the local level, the government institution efficiently managing the Quarantine centres, Community Kitchen for COVID-19 infected persons, and persons in isolation. The initiatives for Kerala Sannadhasena consist of more than 2.5 lakh peoples, the members of the Army are ready to volunteer at any time of any disaster in the state. One hundred people are trained as a volunteer. The members of the army are 16-65 years old. Their education or physical fitness does not preclude them from joining the army. The state and central government need to give more care to Local Self Governments in the process of fighting against COVID-19.

\section{INTRODUCTION}

The COVID-19 pandemic created a profound effect on local governance around the world. In addressing the pandemic local governments are stand-in frontline. Local self-government is playing an important role in the protection initiatives by ensuring protection measures distribution, scientific proper management of transport system and disposal of waste, and examining the availability of protection measures and response team is well equipped. In public places, institutions and markets need to follow the government rule of taking a social distance from others and use sanitizers, the urban local body's responsibility that to ensure they follow them. The formation and maintenance of community Kitchen and ensuring food availability to those who were in quarantine, making awareness among people, and cleaning public places. Managing all agencies together for one purpose is considered as the most difficult thing and governing bodies need to do the same. This crisis will examine the existing government's accuracy, transparency, and accountability of existing governments and it also influences the local and urban governance entirely.

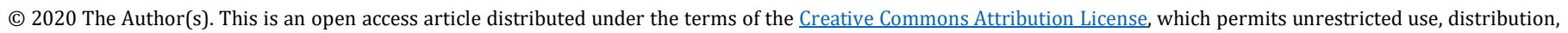
and reproduction in any medium, provided the original author and source are credited. 
Local government bodies are in the front line in serving people, they were the first alarming agency at the time of any pandemic. The guardian role also crates the responsibility of serving basic needs for the people. In the world, scarcity of resources is the most serious problem faced in most of the local governments, in the time pandemic it further boosts their scarcity, and it will result in hazardous results at the local level than by coronavirus. The pandemic enlarges the gap between rich and poor with men and women, through the loss of employment and it further energizes these inequalities [1], [2].

The social distancing is the most important initiative that needs to follow to up by all to save people from the speeding of the virus, the government makes awareness among the people about its need and importance of following, it resulted in a positive impact in social perspective but in an economic perspective, it created a harmful impact. The social distancing reformed the structure of tourism, transportation, and trade, and people start to felt like they were an agency for speeding off the virus, they start to move away for it. In most of the local selfgovernments in Kerala tourism is one of the important sources of revenue and employment generating agency it vanishes from the economy. The increased spread of virus forced the state to follow up lockdown, it created a difficulty for people to find their basic needs, these events farther created a burden on local self-government to satisfy their needs.

This paper lights the efforts taken by the local government with the state government in the creation and management of various initiatives to control the spread of the coronavirus with helping people who were already affected and in quarantine. The peoples who were coming from corona affected states and countries need to be monitored at regular intervals with providing basic facilities. In most cases, local governments were taking their responsibility of providing quarantine centres with food through Community Kitchens [3]. The main objectives of the study to analyse the effect of COVID-19 in Kerala and to suggest the important initiatives taken and managed by Local Self Governments.

\section{RESEARCH METHODOLOGY}

This study is based on secondary data. The required data have been collected from various sources i.e. Kerala Government official COVID-19 database, Kerala Local Self Governments database on COVID -19, Kerala Institute of Local Administration (KILA) documents, Various News Paper articles, World Health Organisations documents on COVID-19, etc. It is a time-series data and the relevant data have been collected for a period of 08 months from January 2020 to August 2020. The data analysis are done mainly based on simple mathematical tools of figures and table for analyse trend of growth in COVID -19 over the period of time.

\section{THE IMPACT OF COVID-19 ON LOCAL GOVERNMENTS IN KERALA}

In Kerala Local governments are in the front in coordinating all services together it includes health workers, police, public workers, Kudumbasree workers, and drivers, volunteers who were delivering food, medicines, and sanitizers to fight against it. The authorities need to give more care and attention to them, out of making it result in a wrong result. They just need to use personal protection measures like masks and gloves compulsorily and sanitize the thinks like mobile, ID Cards, pours, pen, etc. that were frequently used. If there is any sign of fever cough or difficulty in breathing they need to get quarantine immediately and need to avoid close contact with others, avoid their eyes, nose, and mouth touching with clean or disinfect their house and surrounding in certain intervals [4].

\section{KERALA COVID-19 STATISTICS}

In Kerala the corona increases over the day, at the beginning of July there were 151 positive cases with a total of 2130 active cases, the recovery rate is also very high. The important factor the confirm cases never fall in the high amount it becomes 10498 cases at the end of the month with a daily count of 1310 cases. In August the whole days recording more than 1000 cases in a day, in august 19 covered 2000 cases but the recovery rate is not improved as much needed it resulting in an overall result in 18676 active cases in the state. At the beginning of the pandemic, Kerala state government played as an adaptable way to others but it was not continued up to full power. The increased case of breaking rules by social gathering without proper social distancing, not wearing masks, and breaking of quarantine created several social problems and result in holes in government actions. In figure 1 shows 
that the number of cases with death tolls is increasing over the day, but the recovery rate is not equal it increases the active patient's rate. The uncontrolled growth will result in harm full effect in Kerala, it needs to be solved [5].

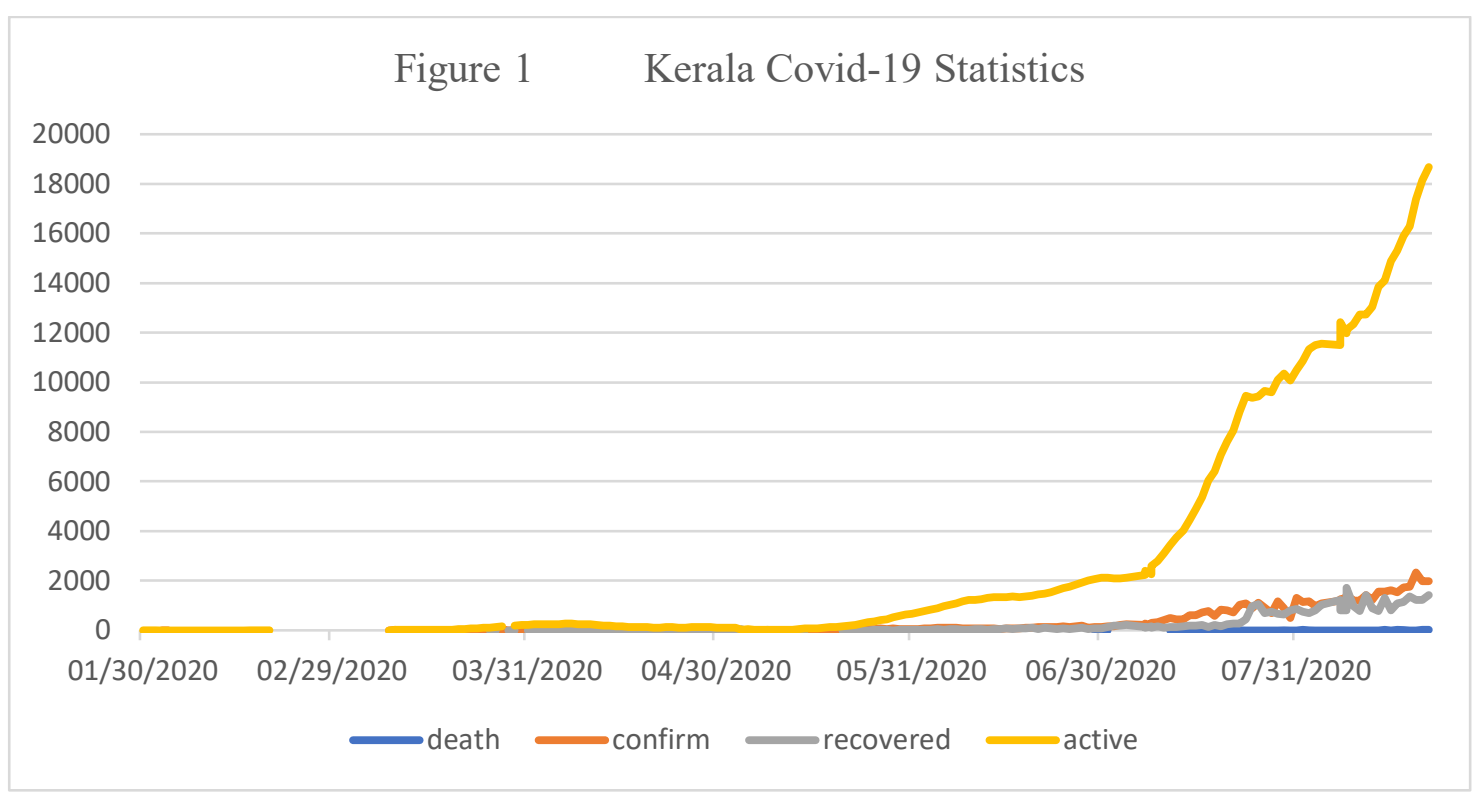

Source: Government of Kerala Database 21.08.2020

\section{QUARANTINE CENTRES MANAGEMENT}

The World Health Organization has declared COVID-19 (SARS - Cov-2) spread as an international health emergency and it covered the whole world and everyone needs to give more care. The process of quarantine controls the spread of the virus through active observation on the patients and finding the COVID affected person in to early and avoiding them from contacting others by transferring the virus. The process prevents the community from spreading as well as contact tracing.

The ensuring of the physical distance is considered as the important factor in the spread of viruses to make this to happen quarantine is the only solution, out of making this step it will lead to spreading of virus and becomes a huge disaster, through the quarantine canter it prevents the virus spread and ensures the physical distance. The peoples who were come from other states or countries, the quarantined person with not enough facilities, and those who broke the protocol during the observation period are quarantined in the community centre, the quarantine centres include Hostels, educational institutions, lodges, resorts, and unused houses and buildings. Quarantine centre is the place were accommodating the person who has not been infected with the coronavirus but has been arrived from the places were in high infection area or a chance for being contact with an already infected person. Through the initiative, it can prevent infection to other persons. In the case of urban local bodies, they have the responsibility to maintain proper water, electricity bed, bedsheet, soap, towel food, and other basic needs. The urban local bodies need to be always ready to accommodate the quarantine centres when an emergency occurs [6].

Table 1: Quarantine District wise data in Kerala

\begin{tabular}{|c|c|c|c|}
\hline Districts & Total & Home & Hospital \\
\hline Thiruvananthapuram & 23147 & 20287 & 2860 \\
\hline Kollam & 8114 & 7349 & 765 \\
\hline Alappuzha & 4195 & 3930 & 265 \\
\hline Pathanamthitta & 5080 & 4776 & 304 \\
\hline Kottayam & 10202 & 9604 & 598 \\
\hline Idukki & 7547 & 6157 & 1390 \\
\hline Ernakulam & 15015 & 13906 & 1109 \\
\hline Thrissur & 9135 & 8512 & 623 \\
\hline Palakkad & 13693 & 12825 & 868 \\
\hline
\end{tabular}


Role of Local Governance During the Covid-19 Pandemic: Evidence from Kerala Experience

\begin{tabular}{|c|c|c|c|}
\hline Malappuram & 36233 & 34431 & 1802 \\
\hline Kozhikode & 14720 & 13372 & 1348 \\
\hline Wayanad & 2761 & 2374 & 387 \\
\hline Kannur & 9079 & 8536 & 543 \\
\hline Kasaragod & 5108 & 4273 & 835 \\
\hline TOTAL & 164029 & 150332 & 13697 \\
\hline
\end{tabular}

Source: Government of Kerala Database 21.08.2020

The impact of COVID-19 is fluctuating over the days according to the formation of clusters. When the number of patients increasing more than hospital limit home isolation become essential and it limits hospital only for serious patients. In Kerala, the districts with high population density were showing high growth due to the high number of contact with COVID-19 patients. The high amount people come back from abroad and other states were COVID-19 impacts are very high also stimulated the number of cases. In Trivandrum, the community spread resulted in a sudden high in patients as like many places the formation of community spread results high impact in health care services, social and economic conditions. The local government role increasing with the number of patients by protecting their needs by providing basic needs for them.

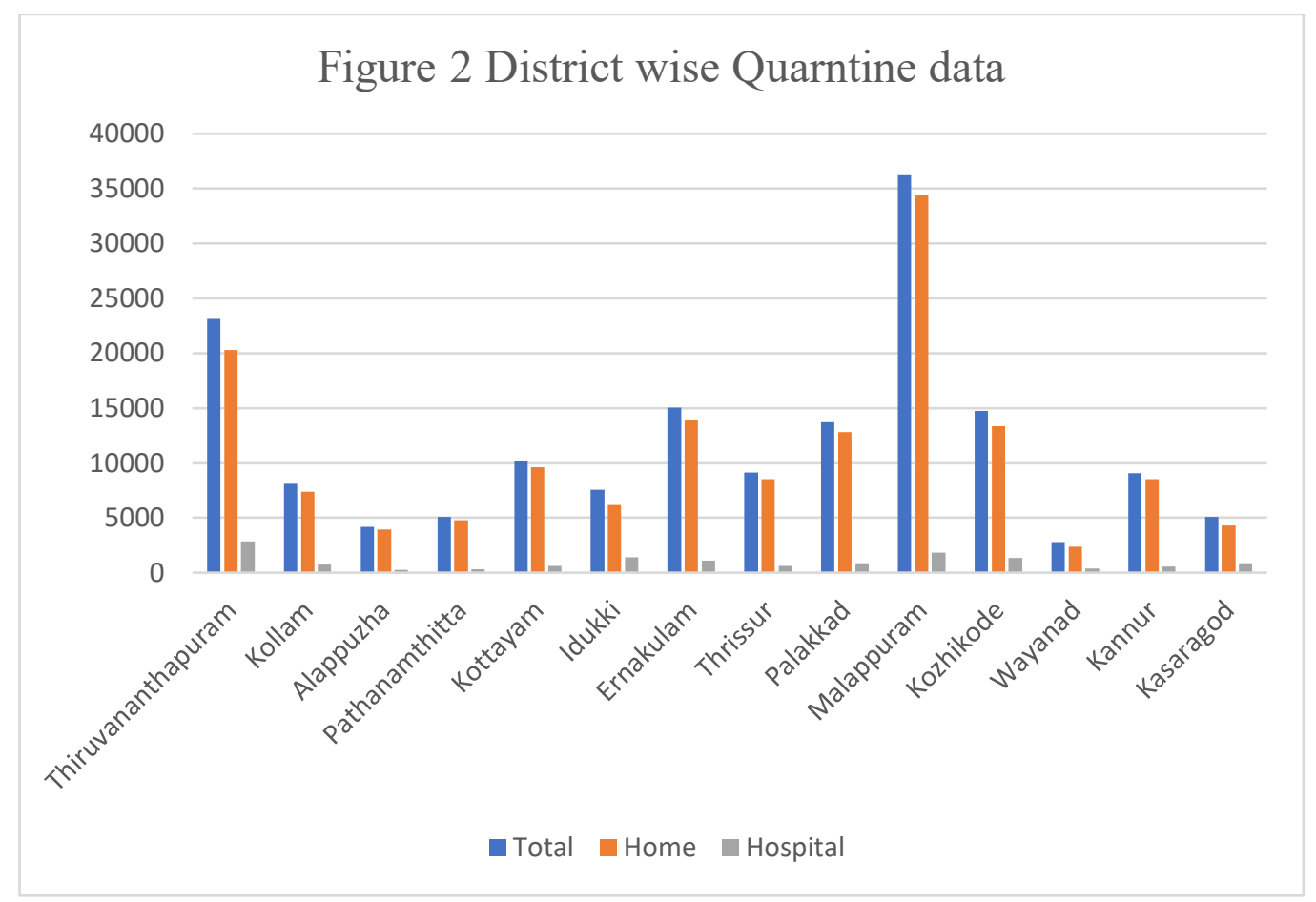

Source: Government of Kerala Database 18.08.2020

\section{THE ISOLATION IN LOCAL SELF GOVERNMENT INSTITUTIONS}

The people with no symptoms and tests positive in coronavirus are need to be isolated from others, it is not good to focus on people with symptoms to non-symptom it results in the formation of isolation camps or home isolation. In most situations, local governing bodies or other agencies are taking care of special isolation vamps for people those have not enough isolation facilities. The people who were in self-isolation are also needed to give more care by making room isolation and avoiding contacts with family members [7].

Table 2: The Isolation in Local Self Government Institutions

\begin{tabular}{|c|c|c|c|c|}
\hline LSGI Type & Municipality & Corporation & Grama Panchayat & Total \\
\hline No. of people on home isolation & 7,049 & 4,516 & 28,299 & 39,864 \\
\hline No. of newly isolated & 465 & 187 & 1,625 & 2,277 \\
\hline
\end{tabular}


Vimal V, and Dr. Vipin Chandran K P

\begin{tabular}{|c|c|c|c|c|}
\hline No. of peoples have been provided food & 20 & 27 & 84 & 131 \\
\hline No. of peoples have been provided counselling & 2,344 & 59 & 10,644 & 13,047 \\
\hline Isolation completed & 285 & 132 & 2,911 & 3,328 \\
\hline
\end{tabular}

Source: Local Self Government Database, Government of Kerala 23.08.2020

In the case of isolation local self-governments were performing their best in Municipalities there were 7049 peoples were in isolation and it is very high in Grama Panchayat with39864 peoples, in that 1625 of them are newly isolated and 3328 of them are completed their isolation. The community Kitchens are mostly focused on the peoples who were in quarantine so it resulted in a low amount of care to people in isolation, the people who get food through governing bodies is very low in municipalities as compare to corporations and Grama Panchayats. The pandemic out of making physical difficulties also creates mental stress, it resulted in the formation of counselling services, and more than 13047 services are completed so far with the support of health workers and social volunteers.

\section{GUEST LABOUR FORCE OF KERALA}

In Kerala state labour force, Guest labourers have gained an important part. In the time of the pandemic, it is essential that to fulfil their security and welfare to full this the government must need to give special consideration by forming camps to arrange food and essential services to them. Government officials need to be visited their camps infrequent intervals to make sure there were following the rules. The most important factor that needs to give more care is the collection of data regarding where they come from, travel history how money people were contacted. The data collection becomes more difficult when the labours are structured over a large area. In each quarantine centre, there needs to use a translator who can handle both Malayalam and their regional language to make sure that they were well aware of the government initiative to protect them. When arraigning camps for the guest labours it is good to make small camps and in the place were easily contacted, if there were families it needs to give arraignments also for them [8].

The camps that formed for the guest labours are formed by taking care of the availability of water, electricity, toilets according to the number of people and need to be a clean environment which enables the labours to satisfy and for to maintain hygiene and secured soap and sanitizers need to be available for all and ladies' sanitary pads and disposable facilities are essential. The contractors also have the same amount of importance as government and local bodies in maintaining the camp for guest labours and they need to ensure that they have enough facilities to secure themselves and to follow up social distancing. In the case of food arrangements, it needs to give more importance and provide food according to their preference, by forming a special cooking team or provide Atta, Dal, Big Onion, Oil, etc. to cook themselves.

\section{COMMUNITY KITCHENS MANAGEMENT}

In Kerala during COVID-19 taken an important initiative of Community Kitchens for the people who are in quarantine or isolation at home. Through the scheme, it helps peoples who cannot afford to cook food for their own at home. It also helps poor, beggars, and elder parsons. When lockdown started most of the shops and hotels are stopped it created great difficulties for the guest labours and those who were involved in preventive works and essential services. In each area, the local self-government department takes up vacant canteens, catering units, Kudumbasree kitchens, and auditoriums to start a community kitchen. The service includes both paid and free of cost.

The monitoring committee for the initiative comes out with Local Self Government Chairperson, Standing Committee Chairpersons, Kudumbasree official in charge, Health Inspector/Health Supervisor, and a nongovernmental organization representative nominated by the Local Self Government. In each community kitchen in local self-government level prepares food for more than 1000 peoples at the rate of Rs 20 per person, rice for the cooking are purchased from Raton depots at the rate of rs10.9 per kg and vegetables and groceries were from supply co. In certain situations, free meals also to be provided by taking sponsorships from agencies or converting development funds or own funds and free food needed beneficiaries' lists were prepared in advance and Volunteers also deliver food into home. The number of required volunteers determines according to the route for the food supply and they were completing it promptly and the training is provided in advance [9]. 
Role of Local Governance During the Covid-19 Pandemic: Evidence from Kerala Experience

Table 3: Community Kitchens Management in Governing Bodies of Kerala

\begin{tabular}{|c|c|c|c|c|}
\hline LSGI Type & Municipality & Corporation & Grama Panchayat & TOTAL \\
\hline No. of Community Kitchens Started & 45 & 11 & 296 & 352 \\
\hline No. of Kudumbasree Community Kitchens & 14 & 11 & 141 & 166 \\
\hline No. of LB Community Kitchens & 28 & 0 & 152 & 180 \\
\hline No. of NGOs Community Kitchens & 1 & 0 & 1 & 2 \\
\hline No. of Other Community Kitchens & 2 & 0 & 2 & 4 \\
\hline
\end{tabular}

Source: Local Self Government Database, Government of Kerala 18.08.2020

In Kerala, Local bodies were playing an important role in this pandemic time through the creation and maintenance of community kitchen and delivering food to needed ones. In 352 total community kitchens, 180 are maintained by local bodies, especially Grama panchayats. The $16 \%$ of community kitchens were only in urban local bodies and on it, $80 \%$ are in municipalities and remaining in corporations. Kudumbasree also playing a crucial role through the creation and maintenance of 166 community kitchen by 141 in Gram Panchayat, 14 in Municipalities, and 11 in Corporations. In municipalities and corporation area NGOs were also formed community kitchens to help people in the time of the pandemic.

Table 4: Food distribution through Community Kitchen in Kerala

\begin{tabular}{|c|c|c|c|c|}
\hline LSGI Type & Municipality & Corporation & Grama Panchayat & TOTAL \\
\hline No. of peoples have been provided food & 2,891 & 782 & 2,865 & 6,538 \\
\hline No. of peoples have been provided free food & 2,085 & 33 & 1,165 & 3,283 \\
\hline Total Home Delivery & 586 & 126 & 1,514 & 2,226 \\
\hline
\end{tabular}

Source: Local Self Government Database, Government of Kerala 18.08.2020

Through community kitchen 6538 peoples who get food in this $44 \%$ each from municipalities and gram panchayat and the reaming $12 \%$ from corporation. The distribution of food in a free of cost is considered an important need for those who lose their job, unable to move for work, and poor families through community kitchen 3283 peoples were got free food and 2226 people get food in-home delivery. The distribution of free food is very high in municipalities than gram panchayats but in-home delivery is gram panchayat serves very well.

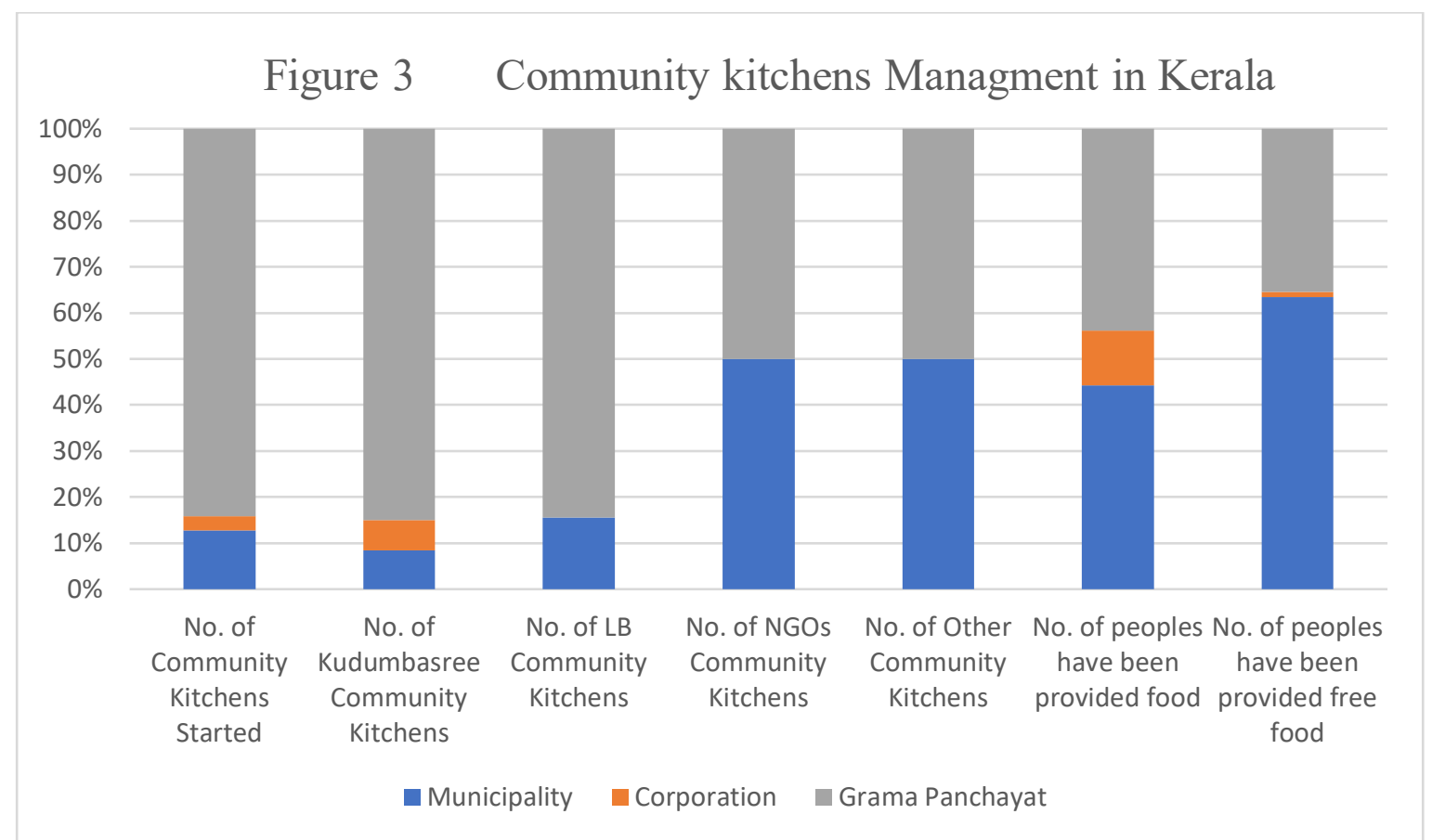

Source: Local Self Government Database, Government of Kerala 18.08.2020 


\section{KERALA SANNADHASENA}

It is the Kerala state youth volunteer force to fight COVID-19 more than 2.36 lakh youths from different local bodies between the ages of 22 to 40 years. In each panchayat, they need to identify 200 volunteers, municipalities each one pick 500 volunteers, and six corporations will pick 750 volunteers. They perform various responsibilities including cook foods, delivering food packets to families who were in quarantine or unable to buy food packets or difficult to reach shops. The peoples need help so the volunteers helping them with other service sources including Community Kitchen and social groups. The registration for the volunteers was done online and those who were willing they were registering in the portal. The main objective of the scheme is to ensure one volunteer for a community of 100 people and they need to participate in the public platforms including relief camps. The volunteers may take from inside or outside Kerala with various skills to act in emergencies [10].

The force includes the Malayalee's from domestic or foreigners who were ready to join the defence system and willing to go lengthy training, who are ready to act in emergencies with various skills. The Social Volunteer Force should be considered as a unified form. The ward-based emergency response team who were in the activities related to the formulation of disaster extenuation plans by governments.
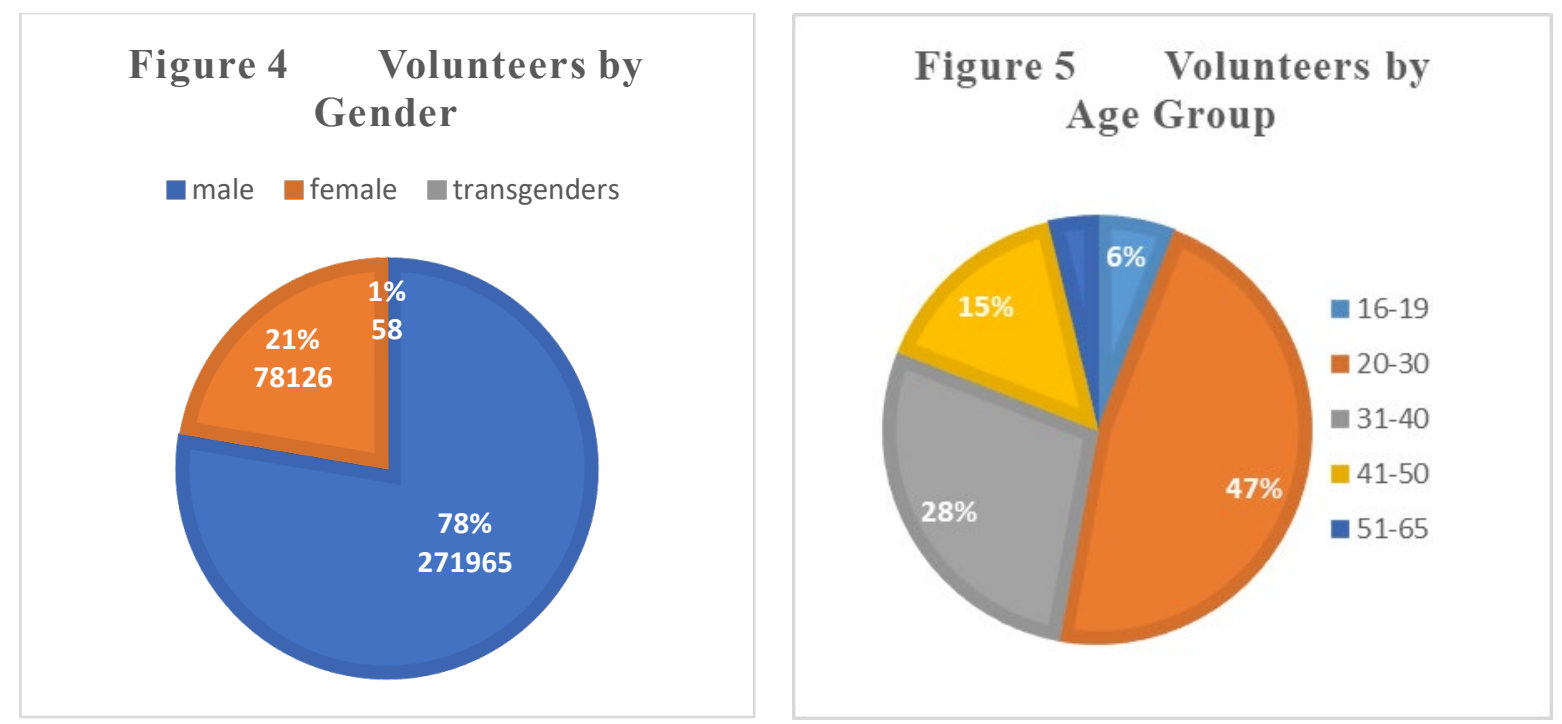

Source: Government of Kerala Database 18.08.2020

In the social force Gender is not a barrier for serving. In volunteers, it cumulates male, female, and transgender with an army of 350149 peoples. Table 5 indicated that in the army $78 \%$ of peoples are men, $21 \%$ are female, and reaming $1 \%$ are represented by transgender. The women's forces are formed against the social and cultural barriers created by social evils. The volunteer force helps police and health care workers to improve their performance. The volunteers don't mean youngsters it includes all age groups like the Kerala volunteer force contains people from all age groups from 16 to 65 years. In figure 4 also shows that majority of the area is covered by male but still it doesn't mean female is incapable, the service that they did are outstanding. The effective participation of transgender needs to be appreciated there were small only by number not by power, societies acceptance will enlarge their participation in the future. Table 6 indicated that in force, 47\% of them are in-between age group of 20 to 30 years, and the combination of age of group 20 to 40 years represents $75 \%$ of the force. The people above 50 years are also volunteered to work for our society are considered an important factor in community service. In figure 5 indicates the youngsters are well aware of social conditions they were formed as a big force for serving in a pandemic situation, it destroys the statements that youngsters are moving away from social responsibilities. [11]

Table 5: Volunteers in COVID-19 Efforts

\begin{tabular}{|c|c|}
\hline Category & Count \\
\hline Identification of Those Who Needs Assistance & 119390 \\
\hline Delivery of Food/Essential Items & 122037 \\
\hline Procurement of Locally Produced Goods & 93110 \\
\hline
\end{tabular}


Role of Local Governance During the Covid-19 Pandemic: Evidence from Kerala Experience

\begin{tabular}{|c|c|}
\hline Emergency Assistance at Homes & 94305 \\
\hline Call Centre Operations & 77910 \\
\hline
\end{tabular}

Source: Government of Kerala Database 21.08.2020

Table 6: Activity based Volunteer Count

\begin{tabular}{|c|c|}
\hline Category & Count \\
\hline Control Room Operations & 52138 \\
\hline Relief Work & 136912 \\
\hline Delivery of Materials to Camps & 121418 \\
\hline Communicating Alerts & 86393 \\
\hline Help in Hospitals & 135189 \\
\hline
\end{tabular}

Source: Government of Kerala Database 21.08.2020

Through the force helped the health workers and government agencies to identify those who need assistance, delivering the essentials, procuring locally produced and distributing among the needed persons, giving emergency assistance at home for health and other problems and provide assistance in call centre operations solving queries of others regarding corona and related issues. Through this service volunteer force helped people who make the need for assistance through delivered food and essential items to 121418 individuals with volunteers of 122037 persons with a force of 93110 of them were procured locally produced goods and delivered in community kitchen centres to help who were stayed in home isolation and those who unable to find food. In communication service, 77910 volunteers are served to help 86393 individuals' quarries to spurred awareness. The 119390 volunteers were served to identify the persons who need assistance and 94305 volunteers are readied for the emergency assistance at home they did 136912 relief works in the society with assistance for 135189 activities.

\section{CONCLUSION}

Despite the difficult situation of the COVID-19 crisis, local governments and their communities have moved into the action mode straight away, with relevant stakeholders on their region. The local governments are taken several initiatives in local public health care by distributing gloves and sanitizers to volunteers, informing the public about this crisis, and making awareness among them. The fight against corona is not going to get over by a few days or months, day by day it worsening the situation in further it transferred the process of making quarantine to reverse quarantine. Through reverse quarantine, it covers the peoples who contacted with corona infected person, in some situations it can destroy the whole system. The difficulty in quarantine is finding route maps, after that need to prepare quarantine centres for them with food and other essential needs. They were also taking initiatives to prevent the outbreak of the virus by cleaning the buildings and offices infrequent intervals. The initiatives taken to help and support guest labours are appreciable one, in the most area they were considered only as of the second citizen but in Kerala ensures the same amount of care and treatment also for them. In self-governing institutions, the important problem faced by them is the shortage of resources in case of public health, they have only limited equipment for sanitizing, shortage in masks, and protection equipment's for health workers. In most events, they consume a huge amount of money, with limited financial stability local governments are in the struggle to fulfil these initiatives [12].

The availability of water and waste management needs to ensure in areas under governing body, they need to coordinate with other agencies who were with the same objective but fall in tax revenue limited capacity were further forming barriers. In local level resource allocation need to be efficient and policy's to be form based on local governance level otherwise it will destroy the effective distribution. The most budget plans were destroyed and it resulted to perform new duties than expected they were performed well, that why the areas were rescued from community spread. The collective work of Kerala state government, local and urban governing bodies, volunteers, Health workers, and police force performed well together to save people from the pandemic. The external actors and the international community to support local governance deal with this crisis. 
Vimal V, and Dr. Vipin Chandran K P

\section{SOURCES OF FUNDING}

This research received no specific grant from any funding agency in the public, commercial, or not-for-profit sectors.

\section{CONFLICT OF INTEREST}

The author have declared that no competing interests exist.

\section{ACKNOWLEDGMENT}

None.

\section{REFERENCES}

[1] …..........(n.d.) (2020) Department of local Self Government, Kerala

[2] Asia, S. (2020). Responding to COVID-19 - Learnings from Kerala. 1-5.

[3] April, V. N. G. I. (2020). Briefing and preliminary policy recommendations on the role of local government in the international COVID-19 crisis response.

[4] Report, S. (2020). Coronavirus disease 2019 (COVID-19). 2019(April).

[5] Kerala government official COVID 19 database

[6] Centers for disease control and prevention. (2020). Coronavirus Disease 2019 (COVID-19) Social Distancing Social Distancing What is social distancing? Why practice social distancing? 2019, 2019-2020.

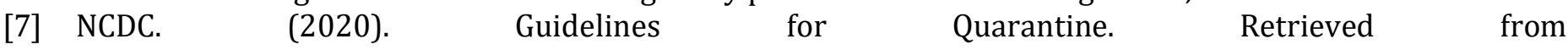
https://www.mohfw.gov.in/pdf/90542653311584546120quartineguidelines.pdf

[8] Self-governments, G. F. O. R. L. (2020b). Municpality implementing team.KILA

[9] Mbabazi, J., Kasalirwe, F., Atukunda, P., \& Akena, W. (2020). Cushioning Local Governments from the Impact of COVID-19. (50), 1-7.

[10] Self-governments, G. F. O. R. L. (2020a). Guide for Local Self-Governments session 7 volunteers: area of work, duties. KILA

[11] For, G., \& Self, L. (2020d). Subhiksha Kerala- Goals and Mechanisms Subhiksha Kerala - Goals. KILA

[12] Kerala, G. O. F. (2020). session 4 covid 19 preventive measures guide for Local Self Governments.

\section{Websites}

[1] https://dashboard.kerala.gov.in/ck-view-public.php

[2] https://dashboard.kerala.gov.in/index.php

[3] https://covid19kerala.com/

[4] https://covid19kerala.info/

[5] http://dhs.kerala.gov.in/public-health-2019-n-corona-virus/

[6] https://www.kila.ac.in/

[7] https://pandemicmis.lsgkerala.gov.in/ 